\title{
THE INFLUENCE OF LIQUID WALET EXCRESSION FERTILIZER TOWARDS PLANT HEIGHT AND AMOUNT OF LEAVES IN PLANT JELUTUNG RAWA (DYERA POLYPHYLLA (MIQ.) STEENIS)
}

\author{
Rahmawati Reni \\ Department of Forestry, Faculty of Agriculture, University of Palangkaraya, Indonesia \\ E-mail: renirahmawati@for.upr.ac.id
}

\begin{abstract}
This research was done to determine the influence of liquid walet expression fertilizer towards plant height and amount of leaves in plant jelutung rawa (Dyera Polyphylla (miq.) Steenis). This plant is an endemic type of plant that needs to be developed especially in Central Kalimantan. This study uses a randomized block design (RBD) consisting of 2 groups of observations. the first group observed open areas, the second group observed areas of shrub cover, consisting of 5 levels of treatment with 16 replications. Measurement of light intensity at the study site using a light meter. Analysis of the data used is the analysis of variance for RCBD with linear models. Based on the results of the study it was found that the administration of liquid swallow excretion did not have a significant effect at the level of $5 \%$ and $1 \%$ of the variable increase in Jelutung Swamp plant height in both open and closed areas. Liquid swallow excretion gives a significant effect on the variable number of leaves at $5 \%$ level in both open and closed areas.
\end{abstract}

\section{KEY WORDS}

Swallow liquid excretion, liquid swallow dose, plant height, amount of leaves.

Swallow's nest business in the city of Palangka Raya itself has developed and many people are opening a swallow breeding business. The process of excretion / feces and urine from these animals around the nest, then the feces are eaten again by beetles or other microbes to form organic guano fertilizer. The mineral content of the fertilizer is the main elements such as nitrogen, phosphorus, potassium, calcium, magnesium, and sulfur in varying amounts.

The swallow's nest saliva itself has many benefits. Usually swallow breeders will clean the swallow bird's house every month from manure so that bird health is maintained and prevent diseases that can reduce the quality of the nest, but without our knowledge the swallow's excretion can actually be used as organic fertilizer to increase plant growth so that it can grow optimally. The use of swallow excretion in agriculture is no stranger, many farmers have succeeded and get maximum results with the use of swallow fertilizer, but in the field of forestry plants very rarely use swallow excretion fertilizer as a trigger for plant growth. One of the plants that uses swallow excretion fertilizer is Jelutung Rawa. Reni (2019) it looks like the Ramin plant, general growth stimulation carried out in silviculture is maintenance with clearance.

Jelutung Swamp plant is one of the recommended types of plants to be developed in Central Kalimantan, because Jelutung Swamp has good benefits in the economic and ecological fields. This plant grows in peat swamp forests and is suitable to be developed as reforestation and rehabilitation plants in an effort to reduce forest damage, especially peat swamp forests due to exploitation, forest fires and land (Yudha, 2017). Swamp jelutung cultivation really requires silvicultural techniques.

The results of the research by van den Wijngaard et a. (2004), Sinha et al. (2010), Talino et al (2013), Greene (2013), Dossey et al. (2016), showed that the application of liquid swallow excretion fertilizers in agricultural crops, namely red spinach, can increase growth and production. According to Lestari (2011), the composition of swallow organic fertilizer is Phosphorus 14\%, Phosphate P2O5 dissolved in citric acid 10\% Nitrogen 1-2\%, Potassium $1 \%$. Organic matter reaches $24 \%$ and maximum water content is $5 \%$, the quality of organic 
guano swallow fertilizer has advantages because it meets national organic agricultural product standards, the application of guano organic fertilizer is expected to improve soil conditions both physically, chemically and biologically.

\section{MATERIALS AND METHODS OF RESEARCH}

The study was conducted for 5 (five) months, starting from August to December 2019. The research was conducted at the Seed Garden Semai UPR Green Campus Area whose land is located on Jl. Yos Sudarso, Kota Palangka Raya.

The design used is with 2 groups. The open area observation group, group II observed the area covered with shrubs, consisting of 5 levels of treatment with 16 replications, so that the total number is 160 tillers.

Swamp jelutung plant (Dyera Polyphylla (miq.) Steenis) planted in 2018, with an average plant height of $10 \mathrm{~cm}-30 \mathrm{~cm}$ seedlings originating from nurseries in BPDAS-HL Kahayan. Swallow Excretion Liquid: with different compositions, namely $0 \mathrm{gr} / \mathrm{L}$ per crop (Control), $50 \mathrm{gr} / \mathrm{L}$ per crop, $100 \mathrm{gr} / \mathrm{L}$ per crop, $150 \mathrm{gr} / \mathrm{L}$ per crop, and $200 \mathrm{gr} / \mathrm{L}$ per crop.

Research implementation: the first step taken is to clean each line of Jelutung Rawa plant. Continue to prepare the fertilizer and weigh the swallow excretion fertilizer according to the required dose, and then mark each path of the Swamp Jelutung plant to be observed. After being marked, it is then observed and fertilized once every 2 weeks with a study period of 5 months. The next process is to perform maintenance on plants by watering twice a day ie morning and evening, then measuring height and counting the number of leaves 1 time per 2 weeks for 5 months. For the process of liquefaction of swallow excretion, the first time is done by preparing swallow excretion fertilizer that has been stored for \pm 4 - 5 months, then weighing swallow excretion fertilizer according to what is needed in fertilizing. After weighing, swallow excretion fertilizer is still solid with ground water, after the material has been mixed, the fertilizer is evenly mixed until the fertilizer is completely dissolved with water. The final step is to put fertilizer in a large bucket and incubated for 7 days and the bucket closed tightly.

Data collection about plant height is measured by two weeks for 5 months and measured from ground level to top of the plant, while the number of leaves in the calculation is done every two weeks for 5 months.

Data were analyzed using analysis of variance or analysis of variance (ANOVA) for RCBD. If the treatment shows different effects (at the level of $5 \%$ and $1 \%$ ) then proceed with further testing. Before further testing is done, the coefficient of diversity $(K K)$ value is determined first. The alternative follow-up test that will be used is If the $\mathrm{KK}>10 \%$ then the follow-up test used is the Duncan test, if the $\mathrm{KK}$ is between $5 \%-10 \%$, the follow-up test used is the Least Significant Difference Test, whereas if the KK $<5 \%$ then the follow-up test used is Real Honest Difference.

\section{RESULTS AND DISCUSSION}

Increased Tiller Height in Open and Closed Areas. The availability of nutrients in the soil greatly affects plant growth, if nutrient deficiency occurs it can cause plant growth to be disrupted. The average height increase of Jelutung Swamp tillers in each treatment giving fertilizer doses in an open area can be seen in Figure 1.

Figure 1 is a diagram of the average height increase of Jelutung Swamp tillers in open areas where in the figure it can be seen that, $\mathrm{P} 1$ has the highest average value of $20.93 \mathrm{~cm}$ and P0 has a value of $19.32 \mathrm{~cm}$, in P3 with a value of $14.05 \mathrm{~cm}$, and in P4 has a value of $17.59 \mathrm{~cm}$. The lowest height of tillers at P4 with a value of $13.24 \mathrm{~cm}$. This diagram shows that the best dose or treatment for the growth of Jelutung Rawa is $\mathrm{P} 1$ with an average height of $24.93 \mathrm{~cm}$, with a dose of liquid swallow excretion of $50 \mathrm{gr} / \mathrm{L}$ per hectare while the lowest at P2 average height is 13.24 and administering a dose of $100 \mathrm{gr} / \mathrm{L}$ per crop. From the results of the average height increase of tillers in open areas it can be seen that the administration of liquid swallow P1 excretion dose is the best dose for sapling growth. This 
shows that the application of fertilizer with the right dose can increase the average plant height better.

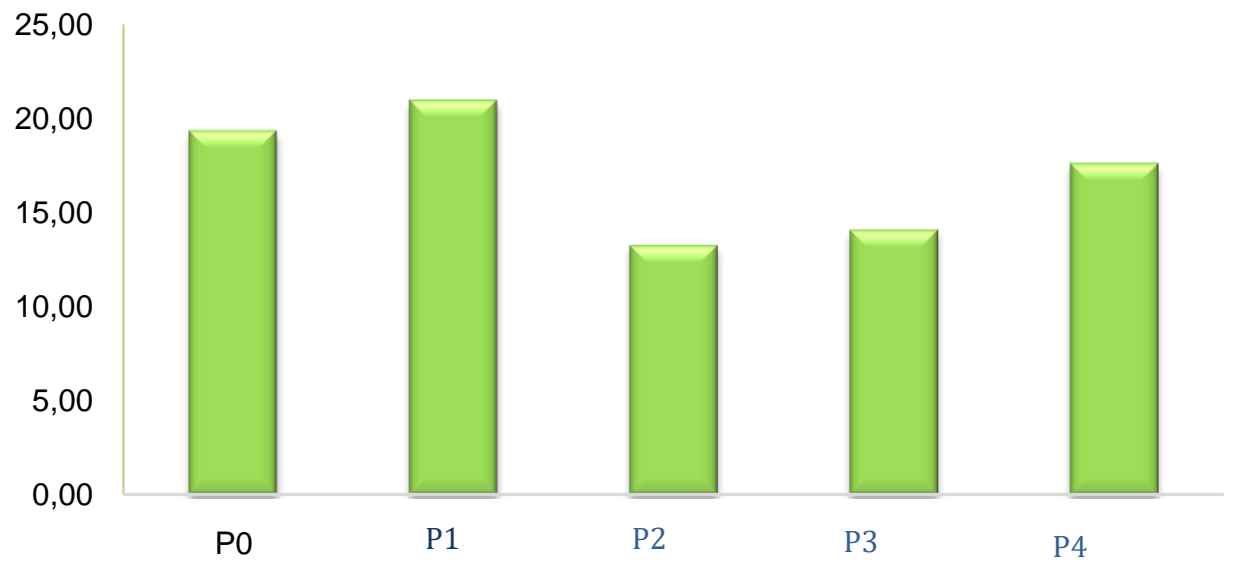

Figure 1 - The height increase of Jelutung Swamp tillers in Open Areas

Anova test results influence the application of several types of fertilizers to the height of Swamp Jelutung for open areas can be seen in Table 1.

Table 1 - Height of Swamp Jelutung Swamp Open Area

\begin{tabular}{cccccccc}
\hline SK & DB & \multirow{2}{*}{ JK } & \multirow{2}{*}{ KT } & \multicolumn{2}{c}{ F Statistic } & \multicolumn{2}{c}{ F table } \\
\cline { 6 - 8 } & & & & & & 0.05 & 0.01 \\
\hline Treatment & 4 & 703.57 & 175.89 & 1.70 & tn & 2.53 & 3.65 \\
Group & 15 & 1505.46 & 100.36 & 0.97 & tn & 1.84 & 2.35 \\
Error & 60 & 6192.96 & 103.22 & & & & \\
Total & 79 & 6192.96 & & & & & \\
\hline
\end{tabular}

The average height of tillers Jelutung Swamp accretion on covered area for each dose of the treatment shown in Figure 2.

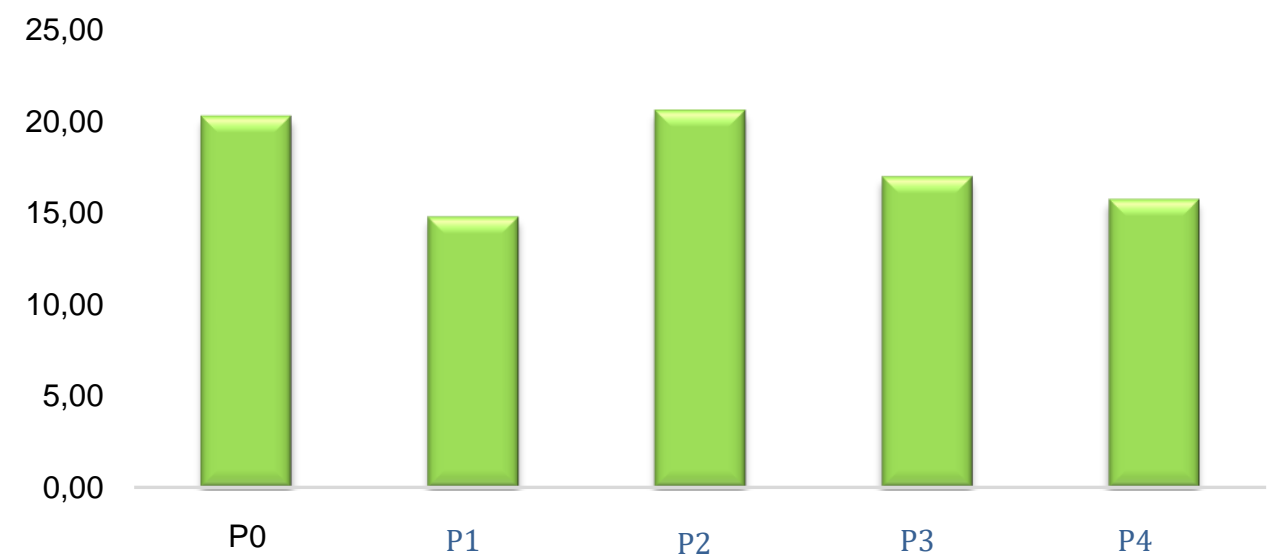

Figure 2 - High Added tillers Jelutung Closed Area Wetlands in

Figure 2 is a high gain tillers Jelutung Wetlands in enclosed areas where the differences with the visible image height increase for open areas, where in closed areas that in P2 has the highest average value of $20.53 \mathrm{~cm}$ and in P0 with an average value of 20.20 $\mathrm{cm}$, whereas in P3 it has a value of $16.91 \mathrm{~cm}$, in P4 it has a value of $15.68 \mathrm{~cm}$ and the lowest average height in $\mathrm{P} 1$ with a value of $14.71 \mathrm{~cm}$. In this case, it can be seen that the diagram shows that the best dose for the growth of Jelutung Rawa tillers for a closed area is P2 by giving $100 \mathrm{~g} / \mathrm{L}$ per planted liquid swallow excretion, while the lowest is in P1 treatment by 
giving $50 \mathrm{~g} / \mathrm{L}$ per plant.

Anova test results influence the administration of several doses that have been determined to increase the number of leaves of Jelutung Swamp for closed areas can be seen in Table 2.

Table 2 - Height Increase of Swamp Jelutung Swamp Covered Area

\begin{tabular}{cccccccc}
\hline SK & DB & \multirow{2}{*}{ JK } & \multirow{2}{*}{ KT } & \multirow{2}{*}{ F count } & \multicolumn{2}{c}{ F Table } \\
\cline { 6 - 8 } & & & & & & 0.05 & 0.01 \\
Treatment & 4 & 445.36 & 111.34 & 1.25 & tn & 2.53 & 3.65 \\
Group & 15 & 2127.06 & 141.80 & 1.59 & tn & 1.84 & 2.35 \\
Error & 60 & 5354.80 & 89.25 & & & & \\
Total & 79 & 7927.23 & & & & & \\
\hline
\end{tabular}

The results of the diversity analysis test where in table 1 in the open area and table 2 in the closed area show that the treatment given has no significant effect on the level of $5 \%$ or $1 \%$, this is presumably due to the lack of time used in this study, so the high increase has not shown any influential results, This is commensurate with Helena's statement (2012) which states the response of plants to liquid swallow excretion fertilizer which is organic fertilizer is not as fast as inorganic fertilizer.

Besides that, the effect of liquid swallow excretion fertilizer on the high increase of swamp jelutung saplings is allegedly due to rainfall conditions where during the months of August to October the rainfall is erratic which results in the lack of availability of nutrients in the tillers, and during research fires that cause smoke to surround the area. so because of this incident the photosynthesis process in the tillers did not go well because sunlight was covered by smog and sunlight was not optimal resulting in unstable tillers. It is also necessary to regulate various physiological processes of plants such as maintaining water conditions in cells and tissues, regulating turgor, 43 closing stomata, regulating the accumulation, and translocation of newly formed carbohydrates (Simamora \& Salundik, 2006).

Neither the group nor the treatment had a significant effect on the closed area, this is due to some locations having different land and environmental conditions, especially the presence of shade from other crops, Sinaga (2018), states that there are several factors that influence the success of growth, namely the environmental conditions in the form of water and nutrients in the soil, sunlight, heredity and others, besides the growth of weeds around tillers that can become competitors for Jelutung Swamp plants so that competition between plants are getting tighter.

Plant height increase occurs due to the growth of new shoots, generally height increase is centered on the apex (tip) of the plant but plant height increase is influenced by two important factors namely genetic factors (internal factors) and environmental factors (Goudenhooft et al., 2019; Ali et al., 2020; Cao et al., 2020; Raffo et al., 2020). The results of giving liquid swallow excretion fertilizer to Jelutung Rawa tillers that have been carried out for 5 months, with the number of measurements 6 times starting from August to October have a different effect from each treatment in both open and closed areas.

The treatment had no significant effect on plant height increase, but on the growth of Jelutung Swamp tillers where each treatment given to the replication gave a different response both in open and closed areas. In the open area, especially in the P1 height increase of $20.93 \mathrm{~cm}$, it showed a more significant height increase with a fertilizer dose of 50 $\mathrm{gr} / \mathrm{L}$ per hectare but for the lowest height increase in P2 was $13.24 \mathrm{~cm}$. The increase in height in the PO (control) treatment was quite high at $19.32 \mathrm{~cm}$ where the environmental conditions also greatly affected the growth of tillers. However, it is different with the height increase in a closed area where P2 shows growth, especially the height increase which is more significant with a fertilizer dose of $100 \mathrm{gr} / \mathrm{L}$ per crop. This is due to the presence of other plants that live around the tillers so that a higher dose is needed by the tillers.

From the results of the data obtained it can be concluded that giving the right dose of fertilizer is highly necessary Jelutung Swamp tillers, this is the same as the opinion 
expressed by Kasniari \& Supadma (2007) which states that each plant with the dose given will affect the speed of growth, but large doses cannot be guaranteed to increase growth, the statement in accordance with the results in treatment 4 for open and closed areas did not provide significant results. According to Kurniawati (2015), Abduh et al. (2020), Guerreiro et al. (2020), Kumar \& Samadder (2020), Verma et al. (2020), organic fertilizer combined with a balanced dose by giving the correct dose to the plant will have a good impact on the growth of the plant itself.

Number of tillers in open and closed areas. The average increase in the number of leaves of Jelutung Swamp saplings for open areas at each given dose is seen in Figure 3.

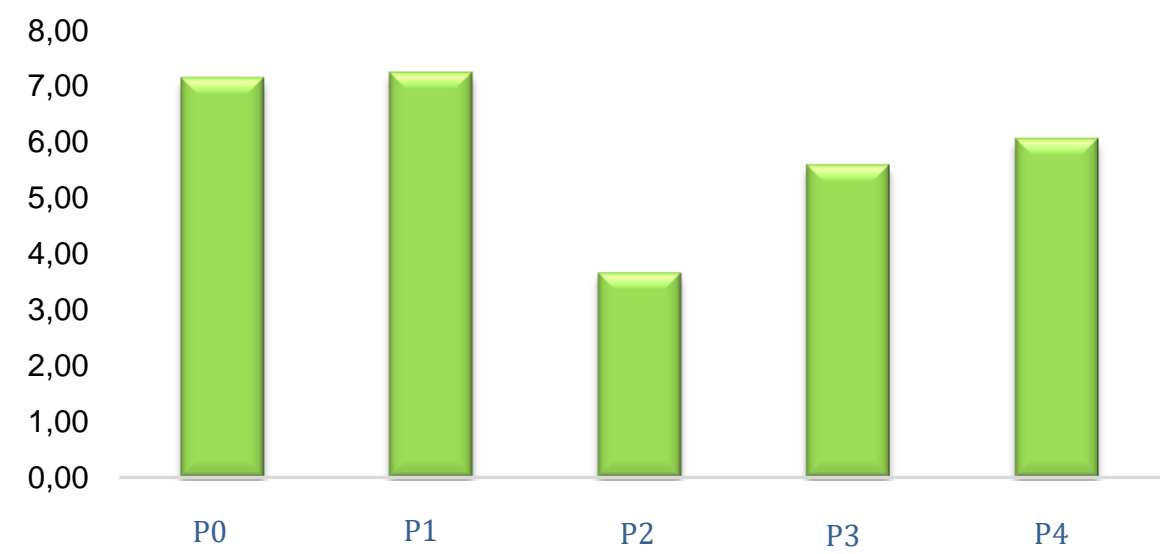

Figure 3 - Increasing the Number of Leaves in Open Areas

Based on Figure 3 results from the average calculation of the number of leaves of Jelutung Swamp saplings in open areas P0 data obtained by $7.13 \mathrm{~cm}, \mathrm{P} 1$ by $7.23 \mathrm{~cm}, \mathrm{P} 2$ by $3.65 \mathrm{~cm}, \mathrm{P} 3$ by $5.58 \mathrm{~cm}$ and P4 by $6.04 \mathrm{~cm}$. The results of the calculation of the number of leaves of Jelutung Swamp for each different dose given for 5 months in an open area, based on these results it can be seen that P1 by giving a liquid swallow excretion dose of $50 \mathrm{gr} / \mathrm{L}$ per plant has the highest average number of leaves that is equal to $7.23 \mathrm{~cm}$ while P0 has a high enough diameter of 7.13. whereas for the lowest average number of leaves in P2 that is equal to 3.65. These results indicate the average difference of each treatment that has been carried out.

Anova test results of the effect of giving several doses to the number of Jelutung Swamp leaves for open areas can be seen in Table 3.

Table 3 - Increasing Number of Till Leaves in Open Area

\begin{tabular}{cccccccc}
\hline SK & DB & \multirow{2}{*}{ JK } & \multirow{2}{*}{ KT } & \multicolumn{2}{c}{ F Statistic } & \multicolumn{2}{c}{ F table } \\
\cline { 6 - 9 } & & & & & & 0.05 & 0.01 \\
\hline Treatment & 4 & 135.08 & 33.77 & 3.11 & $*$ & 2.53 & 3.65 \\
Group & 15 & 171.30 & 11.42 & 1.05 & tn & 1.84 & 2.35 \\
Error & 60 & 651.47 & 10.86 & & & & \\
Total & 79 & 957.84 & & & & & \\
\hline
\end{tabular}

Based on Table 3, significant treatment is therefore necessary to be carried out with further testing. To find out further tests used, the coefficient of diversity (KK) was determined in advance for the average number of leaves in an open area.

$$
\mathrm{KK}=\sqrt{ } \mathrm{KTG} / \mathrm{Y} \times 100 \%=55.63 \%
$$

Based on the results of the Diversity Coefficient which is $55.63 \%$ ie> $10 \%$ then it will be continued with Duncan's further test using the SPSS application with and the following Homogeneous Subsets results are obtained: 
Table 4 - Duncan Test on Number of Leaves in Open Area

\begin{tabular}{|c|c|c|c|c|}
\hline & \multirow{2}{*}{ TillDose_pupuk } & \multirow{2}{*}{$\mathrm{N}$} & \multicolumn{2}{|c|}{ Subset } \\
\hline & & & 1 & 2 \\
\hline \multirow{6}{*}{ Duncan $^{\mathrm{a}, \mathrm{b}}$} & $\mathrm{P} 2$ & 16 & 3.6500 & \\
\hline & P3 & 16 & 5.5750 & 5.5750 \\
\hline & P4 & 16 & 6.0437 & 6.0437 \\
\hline & $\mathrm{PO}$ & 16 & & 7,1250 \\
\hline & $\mathrm{P} 1$ & 16 & & 7,2250 \\
\hline & Sig. & &, 056 &, 203 \\
\hline
\end{tabular}

Means for groups in homogeneous subsets are displayed.

Based on observed means.

The error term is Mean Square (Error) $=10.858$.

a. Uses Harmonic Mean Sample Size $=16,000$.

b. Alpha $=0.05$.

Based on the results of Duncan further tests using SPSS it can be seen that the most significant treatment of repetition is in $\mathrm{P} 1$ by administering a dose of $50 \mathrm{gr} / \mathrm{L}$ of plantations with a value of 7.2250 as shown in Table 4 .

The average increase in the number of leaves of Jelutung Swamp saplings on each treatment dose given in a closed area with a predetermined dose seen in Figure 4.

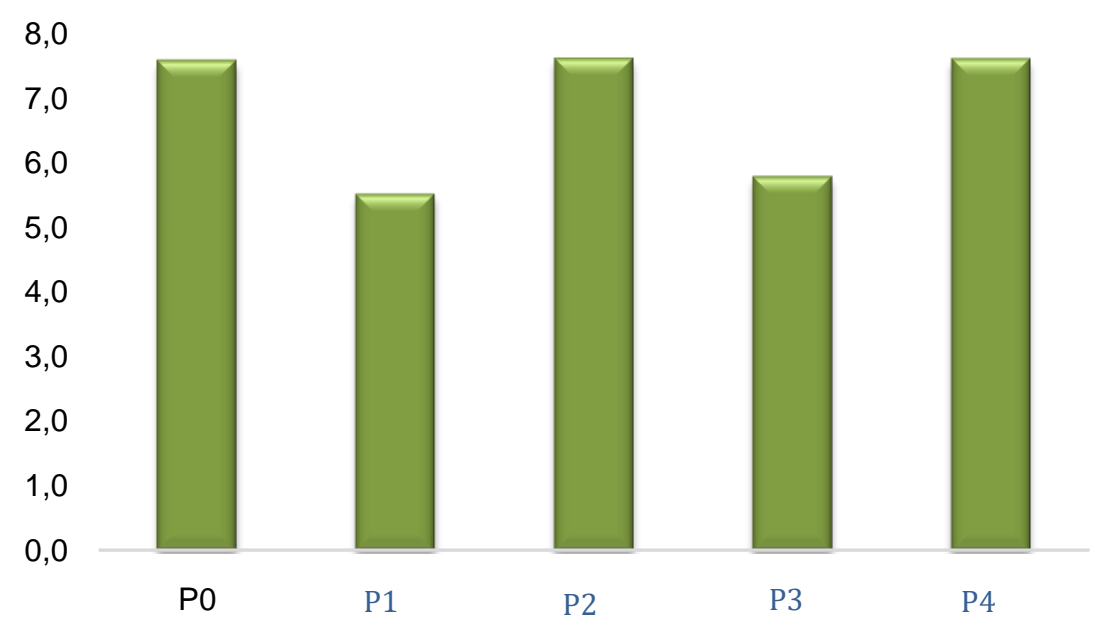

Figure $4-$ Increasing the Number of Leaves in a Closed Area

Based on Figure 4 for the results of the average increase in the number of leaves of Jelutung Swamp saplings in a closed area obtained data at P0 of 7.6, P1 is 5.5, P2 is 7.96, P3 is 5.8 and P4 is 7.6. The average increase in the number of leaves of Jelutung Swamp saplings for each dose of different treatment is carried out for 5 months, based on the results obtained it can be seen that P0, P2 and P4 by giving a liquid swallow excretion dose of $0 \mathrm{gr} /$ $\mathrm{L}, 100 \mathrm{gr}$ respectively / L, $200 \mathrm{gr} / \mathrm{L}$ has the same number of leaves that is equal to 7.6. Whereas the lowest number of leaves in P1 is 5.5.

Anova test results influence the administration of several doses that have been determined on the increase in the number of Jelutung Rawa saplings for a closed area can be seen in Table 6.

Table 5 - The increase in the number of tillers in a Covered Area

\begin{tabular}{cccccccc}
\hline SK & DB & \multirow{2}{*}{ JK } & \multirow{2}{*}{ KT } & \multirow{2}{*}{ F count } & \multicolumn{2}{c}{$\mathrm{F}$ table } \\
\cline { 3 - 8 } & & & & & & 0.05 & 0.01 \\
Treatment & 4 & 73.04 & 18.26 & 2.71 & $*$ & 2.53 & 3.65 \\
Group & 15 & 102.07 & 6.80 & 1.01 & tn & 1.84 & 2.35 \\
Error & 60 & 404.34 & 6.74 & & & & \\
Total & 79 & 579.45 & & & & & \\
\hline
\end{tabular}


Based on Table 5, it can be seen that the treatment gives a significant effect on the increase in the number of tillers in a Closed Area so that further testing is needed. The Coefficient of Diversity $(\mathrm{HH})$ for the average number of leaves in a closed area is:

$$
\mathrm{HH}=\sqrt{ } \mathrm{KTG} / \mathrm{Y} \times 100 \%=38.13 \%
$$

Based on the results of the Diversity Coefficient which is $38.13 \%$ ie> $10 \%$, it will be followed by Duncan's follow-up test using SPSS application with the following Homogeneous Subsets results:

Table 6 - Duncan Test on Number of Leaves in Covered Area

\begin{tabular}{|c|c|c|c|c|}
\hline & \multirow{2}{*}{ TillDose Fertilizer } & \multirow{2}{*}{$\mathrm{N}$} & \multicolumn{2}{|c|}{ Subset } \\
\hline & & & 1 & 2 \\
\hline \multirow{6}{*}{ Duncan $^{a, b}$} & P2 & 16 & 5.5000 & \\
\hline & P3 & 16 & 5.9375 & 5.9375 \\
\hline & $\mathrm{P} 4$ & 16 & & 7.5625 \\
\hline & $\mathrm{PO}$ & 16 & & 7.5625 \\
\hline & $\mathrm{P} 1$ & 16 & & 7.5625 \\
\hline & Sig. & &, 630 &, 106 \\
\hline
\end{tabular}

Means for groups in homogeneous subsets are displayed.

Based on observed means.

The error term is Mean Square (Error) $=6,537$.

a. Uses Harmonic Mean Sample Size $=16,000$.

b. Alpha $=0.05$.

Based on the results of Duncan further tests using SPSS it can be seen that the most significant treatment of repetition is in P1 by administering a dose of $50 \mathrm{gr} / \mathrm{L}$ per plant with a value of 7,5625 .

Table 3 and Table 6 show that the treatment has significant effect as indicated by $F$ count $<\mathrm{F}$ table at $5 \%$ level. This means that the administration of liquid swallow excretion doses has a significant effect on the increase in the number of Jelutung Rawa tillers in both open and closed areas at a significant level of $5 \%$. Whereas the group had no significant effect on both open and closed areas at the level of $1 \%$ or $5 \%$. This is due to several locations having different land conditions mainly due to lack of nutrients for photosynthetic trees and the presence of shade from other plants. Sinaga (2015) states that there are several factors that influence the success of growth, namely the environmental conditions in the form of water and nutrients in the soil, sunlight, heredity, etc. leaf blades, in addition to the growth of weeds around tillers that can become competitors Jelutung Swamp plants, so that competition between plants is getting tougher.

According to Rabumi (2012) leaf formation by plants is strongly influenced by the availability of nitrogen and phosphorus nutrients, where the liquid swallow excretion is known to have a high enough phosphorus content which is good for plant growth. But the element $\mathrm{N}$ in plants is thought to be obtained from the overall combination so that nitrogen nutrients can be a supporter of increasing the number of leaves in the plant.

\section{CONCLUSION}

In this study it was concluded that the dose of liquid swallow excretion did not have a significant effect on the growth of Jelutung Swamp plants in increasing plant height in open and closed areas. For the variable number of leaves, the liquid swallow excretion dose gives a significant effect on the variable increase in the number of plant leaves both in open and closed areas.

The results of this study were obtained that the best fertilizer dose for Jelutung Swamp plant height in the open area was P1 (fertilizer dose $50 \mathrm{gr} / \mathrm{L}$ ) while P2 (fertilizer dose $100 \mathrm{gr}$ $/ \mathrm{L}$ ) in the closed area was the best dose for plants. For the variable number of leaves, in open and closed areas, P1 (50 g / L fertilizer dose) is the best fertilizer dose for plant growth. 


\section{ACKNOWLEDGMENTS}

The author would like to thank the Ministry of Education and Culture of Palangka Raya University and the farmers who helped me in this research.

\section{REFERENCES}

1. Abduh, A. M., Hanudin, E., Purwanto, B. H., \& Utami, S. N. H. (2020). Effect of plant spacing and organic fertilizer doses on methane emission in organic rice fields. Environment and Natural Resources Journal, 18(1), 66-74.

2. Ali, M., Hasan, H., Bux, H., Gul, A., Memon, H. M. U., Khan, A., ... \& Ahmed, M. (2020). Role of transcription factors in drought mediating pathways in wheat. In Climate Change and Food Security with Emphasis on Wheat (pp. 177-192). Academic Press.

3. Cao, S., Wang, Y., Li, X., Gao, F., Feng, J., \& Zhou, Y. (2020). Characterization of the AP2/ERF Transcription Factor Family and Expression Profiling of DREB Subfamily under Cold and Osmotic Stresses in Ammopiptanthus nanus. Plants, 9(4), 455.

4. Dossey, A. T., Morales-Ramos, J. A., \& Rojas, M. G. (Eds.). (2016). Insects as sustainable food ingredients: production, processing and food applications. Academic Press.

5. Goudenhooft, C., Bourmaud, A., \& Baley, C. (2019). Flax (Linum usitatissimum L.) fibers for composite reinforcement: exploring the link between plant growth, cell walls development, and fiber properties. Frontiers in Plant Science, 10, 411.

6. Greene, S. A. (2013). Sittig's handbook of pesticides and agricultural chemicals. William Andrew.

7. Guerreiro, R. C., Jerónimo, E., Luz, S., Pinheiro, H. M., \& Prazeres, A. R. (2020). Cheese manufacturing wastewater treatment by combined physicochemical processes for reuse and fertilizer production. Journal of Environmental Management, 264, 110470.

8. Helena, L (2012). Utilization of Liquid Organic Fertilizer in Tomato Cultivation (SolanumlycopersiumL). Yogyakarta.

9. Kasniari \& Supadma, DN (2018). The Effect of Giving Several Doses of Fertilizers (N, P, K) and Alternative Fertilizer Types on Rice Plant Results (Oryza sativa L.) and Levels of N, P, K Inceptisol Selemadeg, Tabanan. Faculty of Agriculture, Udayana University.

10. Kumar, A., \& Samadder, S. R. (2020). Performance evaluation of anaerobic digestion technology for energy recovery from organic fraction of municipal solid waste: A review. Energy, 117253.

11. Kurniawati, HY, Karyanto, A., \& Rugayah. (2015). Effect of Provision of Liquid Organic Fertilizer and NPK Fertilizer Dose (15:15:15) on Growth and Production of Cucumber Plants (Cucumis sativus L.). Journal of Tropical Agriculture, 3(1).

12. Lestari, EG (2011). The Role of Growth Regulatory Substances in Plant Propagation through Tissue Culture. AgroBiogen Journal, 63. https://doi.org/10.21082/jbio.v7n1.2011.p63-68.

13. Rabumi, W. (2012). Effect of Giving Nitrophoska Elite Fertilizer and Aloe Vera Waste to Growth and Yield of Radish (Raphanus Sativus L.) on Alluvial Soil in Polybag. Panca Bhakti University Faculty of Agriculture Research Journal, 8(2).

14. Raffo, A., Mozzanini, E., Nicoli, S. F., Lupotto, E., \& Cervelli, C. (2020). Effect of light intensity and water availability on plant growth, essential oil production and composition in Rosmarinus officinalis L. European Food Research and Technology, 246(1), 167-177.

15. Reni, R. (2019). Planting Of Ramin (Gonystylus Bancanus Kurz) Wilding In Peat Swamp Thicket Of Central Kalimantan. Russian Journal of Agricultural and Socio-Economic Sciences, 88(4).

16. Simamora, Suhut. And Salundik. (2007). Improving Compost Quality. Library AgroMedia. Jakarta.

17. Sinaga, ER, Rotinsulu, JM, \& Putir, PE (2018). Increased Growth in Shorea Bal Pangeran Korth. in the Palangkaraya University Forest Campus. JPLB, 2(2).

18. Sinha, R. K., Agarwal, S., Chauhan, K., \& Valani, D. (2010). The wonders of earthworms 
\& its vermicompost in farm production: Charles Darwin's 'friends of farmers', with potential to replace destructive chemical fertilizers. Agricultural sciences, 1(02), 76.

19. Talino, H., Zulfita, D., \& Surachman. (2013). Effect of Swallow Manure on Growth and Yield of Green Bean Plants in Alluvial Soils. Agricultural Student Science Journal, 2(2), $1-12$.

20. van den Wijngaard, J. P., Umur, A., Ross, M. G., \& van Gemert, M. J. (2004). Modelling the influence of amnionicity on the severity of twin-twin transfusion syndrome in monochorionic twin pregnancies. Physics in Medicine \& Biology, 49(6), N57.

21. Verma, B. C., Pramanik, P., \& Bhaduri, D. (2020). Organic Fertilizers for Sustainable Soil and Environmental Management. In Nutrient Dynamics for Sustainable Crop Production (pp. 289-313). Springer, Singapore.

22. Yudha, Christopheros, \& Ginting, LV (2017). Effect of Liquid Organic Fertilizer on Growth. Journal of Tropical Forests, 20(2). 